\title{
Exploration of the Theory of Gain Sense in the Political Theory Course of NCO Cadets
}

\author{
Fang Hua, Li Meng, Liu Wenjuan, Wang Zhengyin, Yan Hongxin
}

College of Information and Communication, National University of Defense Technology

\begin{abstract}
The sense of gain of political theory course for non-commissioned officers (NCO) refers to the relatively stable, active and positive psychological experience that non-commissioned officers gain and improve in cognition and behavior, emotion and attitude, thoughts and values, etc., during the teaching and learning process of political theory class[1]. This paper starts with the definition of core concepts, the generation of internal laws and the principles to be followed, and expounds the theoretical related to the sense of acquisition in the political theory course of $\mathrm{NCO}$ cadets.
\end{abstract}

Keywords: NCO cadets; political theory course; gain sense

\section{1. introduction}

As President Xi pointed out at the leading group meeting on comprehensively deepening reform in 2015, the task of reform is to enable the people to have more "gain sense", and the effectiveness of reform should be evaluated by the people's "gain sense", [2] the word "gain sense" quickly became popular, which was a heart-warming word full of people-centered ideas and gave all educators profound enlightenment. Under the background of deepening the reform of ideological and political courses in colleges and universities, how to make the teaching objects of ideological and political courses in military academies enhance the "gain sense" and effectively improve the ability and quality of strengthening and invigorating the army has become the starting point and foothold of the teaching reform. Through the ideological and political theory course education, the military academy makes the cadets get a strong sense of practice and emotional resonance, and really become the "mother of the army" of good political quality, which is particularly important and urgent.

\section{INTRODUCTION: RELATED CONCEPTS OF GAIN SENSE OF NCO CADETS IN THE POLITICAL THEORY COURSE}

Concept is the logical starting point of all researches. Only by clearly defining the main body of "gain sense of political theory course" can we accurately grasp the research object and focus on the research goal and formulate the research strategies.

\subsection{Definition of the gain sense of NCO cadets in political theory course}

"Gain sense" is composed of "gain" and "sense". The definition of "gain" in Modern Chinese Dictionary is the gain of specific things or the gain of abstract things.[3] For "sense", the explanation is response in consciousness and emotion because of the stimulation caused by psychological changes. [4] Thus, " gain sense" can be understood as: An individual's positive subjective experience on the basis of "getting". The NCO cadets of the military academy present the following three distinctive characteristics: firstly, it has an important position. As the head of the army, it is the backbone of the overall construction of the grass-roots level; secondly, the ideological consciousness is higher, they have the study enthusiasm and the clear post quality demand; thirdly, there are differences in cultural foundation. Some cadets don't have a solid grasp of the basic knowledge of politics courses in middle school, and their learning methods and learning ability need to be improved. To sum up, we define the sense of acquisition of political theory courses for NCO cadets as: in the process of political theory teaching and learning, the NCO cadets have gained and improved in cognition and behavior, emotion and attitude, thought and values, etc., and generated a relatively stable, active and positive psychological experience based on this.

\subsection{The specific connotation of the gain sense of NCO cadets in the political theory course}

Specifically, the research group believes that it contains the following three levels of connotation.

The gain sense in the political theory course is the result of the positive interaction between teachers and students. Teaching others teaches yourself, which indicates the teaching process is a two-way interactive process of "teaching" and "learning". On the one hand, if the teaching 
is not effective, students will not have "got", not to mention "gain"; On the other hand, if the class is just the flow of knowledge, students have "get", but do not remember by heart, also do not necessarily have "gain sense". Thus, it can be known that the gain of political theory course includes two forms: passive gain and active gain. The ideal gain class-not just one in which the political teachers actively "give", moreover, it should arouse the students' learning enthusiasm and desire for political theory knowledge and political work skills. With the attitude of "I want to learn" and "I desire to learn", teachers can turn every ideological and political class into a collision of ideas and a dialogue of the soul. The teaching of political theory should advocate the combination of students' passive gain and active gain.

The gain sense in the political theory course is gained both in the process and the result. The "gain sense" can come from the learning process or from the learning results. Through participating in the course of political theory practice, the non-commissioned officer cadets acquire scientific knowledge of political theory and correct guidance of code of conduct, thus producing emotional resonance and value identification, which are then transformed into the conscious behavior of participating in the practice of building a strong army. In class, students gain from the knowledge teaching, logical deduction and emotional interaction with teachers; after class, students can experience and internalize the classroom income in daily ideological and political work practice, and have a peak experience. When the teaching goal and teaching expectation are realized, the students also have the experience of "gaining" both in the classroom process and the socialized result of military political behavior after class. The former is a long quest, while the latter is an intense experience, they are closely related and indispensable. The former is the foundation of the latter, and the latter is the final aim and obtained by the accumulation and transformation of the former.

The gain sense of political theory course is subjective and hierarchical. The gain sense is the "sense" generated by the subject based on "gain", which must have subjectivity and individual difference. Due to the differences in cadets' political quality, learning foundation and ideological and political work practice background, each cadets' gain experience is unique in the face of the same political theory education supply. From the perspective of individual subjective experience, "gain sense" has a process and a hierarchy. Some scholars summarized it as three levels of progressive experience of "gain sense"-perception, satisfaction and peak experience [5]. The difference of this kind of experience depends on the inner needs of the subject. When the subject's needs are small, the "sense" stays at the superficial level of gain. The larger the subject's needs are, the richer and deeper the "sense" will be experienced, and the more lasting and constant the "gain" will be. From the perspective of the latest teaching objectives proposed in the syllabus of political theory course in the military academies, there are both knowledge objectives, capability requirements and value guidance. Correspond to it, the gain experience of the non-commissioned officer cadets in the course of political theory teaching should contain rich levels.

\section{THE FORMATION OF THE GAIN OF SENSE OF NCO CADETS IN THE POLITICAL THEORY CLASS}

Practice has proved that the gain sense of political theory course is a process in which the objective supply and the subject demand are in line with each other, the unity of content gain and subjective feeling, and the result of teaching process and real life.

\subsection{The establishment of the spiritual need for the political theory course is the premise of the gain sense.}

The subjective initiative of the cadets is the premise of the gain sense. Cadets 'spiritual needs should be the vane of teaching reform. The so-called spiritual needs are the spiritual benefits that students can obtain from the course learning. In combination with the special political requirements of the military career and the specific requirements of the $\mathrm{NCO}$ post, the spiritual needs of the $\mathrm{NCO}$ cadets for the political theory course are mainly concentrated in four aspects: the curriculum system knowledge, the concrete ability accomplishment, the political emotion experience and subject ideological value. Taking the history and fine traditions of the people's army as an example, cadets can learn about the glorious history and fine traditions formed by the people's army under the leadership of the party. Through the course learning, cadets will finally be able to analyze and summarize history and reality with the standpoint, viewpoint and method of historical materialism, so as to improve their ability of historical thinking, which is the specific ability literacy; through in-classroom and after-class teaching interaction, cadets could enhance the emotional identification and value identification of the party, the country and the army, and strengthen the political consciousness of inheriting the red gene, which is the political emotional experience. Finally, as a history subject, through course learning, cadets could learn to understand others, learn to observe the future, interpret perceptual knowledge through rational knowledge, and expand one's own life space and time in history, which is the ideological value of the course. Based on this demand, the teaching reform of political theory courses should start from the "supply side" and provide high-quality education content that can meet the demand. 


\subsection{It is an important step to enhance the cadets' gain sense to pay attention to the process of satisfying their psychological expectations in political theory class.}

To a large extent, the degree of gain depends on the degree to which the course meets the psychological expectation of the teaching object, that is, the actual gain of the cadets is positively correlated with the satisfaction of the psychological expectation. Based on the spiritual needs of the teaching objects, each cadet will have a psychological expectation. The more he gets in the teaching, the higher the degree of meeting the psychological expectation and the stronger the natural gain sense. On the contrary, the larger the gap between actual gain and psychological expectation is, the weaker the gain sense is. This principle can be expressed in the following formula: NCO students' gain sense of political theory class=actual gain of teaching/individual psychological expectation. It can be inferred that once the individual gains in teaching practice (including content delivery and emotional care) far beyond his/her own psychological expectations, his/her emotions must be positive, and there would be a strong sense of joy and fulfillment, at the same time, this positive experience will encourage cadets to further exert their subjective initiative and participate in the subsequent learning to form a virtuous cycle. This enlighten us that the teaching reform first is to grasp the direction, according to the teaching outline and the post ability request, guides the cadet to set the reasonable psychological expectation to the course; the second is to pay attention to the teaching effect, follow the principle of unifying the teaching objectives with the cadets' needs, and make efforts accurately and continuously, so that the teaching design and students' psychological expectations in line with the direction and the methods and the aims.

\subsection{It is an important way to enhance and consolidate the sense of political theory course by externalizing the political practice of $\mathrm{NCO}$ cadets.}

Once theories are grasped by people, they will radiate great power. From the teaching process, NCO cadets have a sense of process gain through continuous matching with psychological expectations in the course of political theory. However, the gain sense in this stage is more about the simple recognition of the theory, which is a superficial sense of gain. What's more, it may be an unreal "gain". As we often say, "listen to a lot of truth, still cannot live this life", some gain sense may not be based on the truth of the knowledge, maybe it's just a temporary effect of the teachers' teaching style and chicken soup for the soul. Once cadets find that such "gain" has no guiding significance in real life, even more serious loss will occur. The constant gain sense is embodied in the sense of gain as a result, and in the sense that it can be transformed into another form, either as a material benefit or as a more permanent spiritual accumulation. The objective evaluation criterion is whether this gain sense helps the individual object to enrich and develop on the path of growth. If they can use what they have learned to guide practice, consciously and actively transform the political behavior of the object, and get more positive feedback in real life, then their gain sense will rise to the height of life philosophy and be further sublimated and consolidated. This should also be the ultimate goal of the course of ideological and political theory. Therefore, it is suggested that teachers of political theory should pay attention to the construction of valuable teaching content and deal with the interesting and meaningful choice.

\section{THE PRINCIPLE OF ENHANCING THE GAIN SENSE OF NCO CADETS IN THE POLITICAL THEORY CLASS}

It is a practical process to enhance the students' gain sense of political theory course by adopting scientific and effective teaching methods of political theory course, improving the efficiency of political theory course, and training the new type of high-quality NCO cadets' talents. Compared with traditional teaching, it is more targeted and scientific. No rules, no standards. This requires the political theory teachers must focus on the following three principles in the teaching process:

\subsection{We should stick to the principle of combining with science and direction}

The scientific nature emphasizes the truth and progressiveness of Marxist theory itself, while the directional nature means that the political theory class bears the mission of the times to establish morality and cultivate people. The political theory course is essentially an ideological work, which determines that we must adhere to the combination of science and direction. The teaching goal of the political theory course should be consistent with the training of the grass-roots members who are responsible for strengthening and rejuvenating the army. In the learning stage, it is important to enhance the students' political consciousness to inherit the red gene, so that they can work hard to be contributors to the modernization of national defence and the army. Therefore, political theory courses should start from the new era of our army, adapt to the needs of a strong army, and train qualified personnel. While emphasizing the truth of the mainstream socialist ideology, it helps the cadets to strengthen their ideals and beliefs and define their duties and missions. To guide the sergeant students to combine theory with practice, let the political theory class into the mind and heart, which can consciously apply what they have learned to guide practice, consciously integrate their personal dreams into the dream of a strong army, and realize their personal value in the great journey to realize a strong army and a strong country. 


\subsection{We should stick to the principle of combining with equality and subjectivity}

Equality emphasizes the equality of personality and status between the educator and the educated; Subjectivity emphasizes that educators must fully respect the subjective experience of the gain sense by the educated, reform the traditional education mode, innovate the educational methods and ways, and meet the students' demand for the spiritual interests of the course. In a political theory classroom full of gain sense, the relationship between the two teaching parties must be transformed from the traditional subject-object relationship to an equal relationship of double subjectivity, that is to say, both sides of teaching are subjects in the process of teaching, and the realization of teaching objectives is the result of the interaction between the two sides in the process of teaching and the mutual effect on the object (the purposes, contents and methods of ideological and political education, etc.).Therefore, in the teaching of political theory teachers should fully respect the main position of the NCO cadets, do a good survey of learning situation before class, and find out the students' learning basis and psychological expectations of the course. To adjust the teaching content of the political theory course, we should not only transfer theoretical knowledge, but also combine the experience, characteristics and job requirements of the NCO cadets, include current events in the class that interest them, solve ideological confusion, meet growth needs and career path design; innovate teaching methods bravely, integrate information technology and enhance interactivity, raise the creativity of the classroom, to meet the NCO cadets to the political theory class psychological expectations, so as to enhance the gain sense.

\subsection{We should stick to the principle of combining with practice and motivation}

The practical nature of the political theory course emphasizes that the educational objective must be oriented to practice, the content must be close to reality, and the methods must focus on practical experience; motivation is to use psychology and management motivation theory comprehensively to effectively mobilize and exert the subjective initiative and enthusiasm of cadets in the learning process. First of all, we should pay attention to the teaching based on the improvement of ability, and increase the proportion of practice in teaching, so that cadets can complete self-education in the teaching practice, such as psychological behavior ability training, revolutionary tradition spot teaching and so on. Secondly, we should vigorously expand practical teaching methods of political theory courses, such as relying on the daily management platform of the staff team simulation company and the practice exercise of the army in the third academic year, let the students actually participate in the practice of ideological and political work in the army, deepen what they have learned in class, and improve their practical ability to carry out ideological and political work; finally, take effective course incentive measures. In combination with the specific needs of cadets, political theory teachers must flexibly use various methods and measures such as material and spiritual motivation, extrinsic and intrinsic motivation, positive and negative motivation, such as reform the assessment method, carry out teaching-aid activities, competition, to enhance the initiative of the cadets to participate in the political theory course, so that they can meet the material, spiritual, development, self-realization and other needs.

\section{ACKNOWLEDGMENT}

This paper is the phased achievement of the 2019 annual teaching research project of college of Information and communication, National University of Defense Technology, "Research on Enhancing the Gain Sense of Political Theory Course of Non-Commissioned Officers Vocational and Technical Education".

\section{REFERENCES}

[1] Zhao Jing. The Connotation and Structure of College Students' Gain Sense in Ideological and Political Education, $[\mathrm{J}]$. Studies in Ideological Education, 202003. 51-55

[2] Xi Jinping. Scientific Planning Focuses on the Focal Length, Give the People a Greater Sense of Gain from Reform[N]. People's Daily. 2015-02-28.

[3] Modern Chinese Dictionary [K] Beijing: Commercial Publishing House, 2002, 4th Ed., Page 624.

[4] Modern Chinese Dictionary [K] Beijing: Commercial Publishing House, 2002, 4th Ed., Page 443.

[5] Cheng Shibo, Xiong Jiansheng, On the Gain Sense in Ideological and Political Education, Ideological and Political Education, [J]2017(7) 